\title{
NOTE
}

\section{RESTORATION OF THE OLD SOCIALIST SYSTEM IN HUNGARY AND THE IMRE NAGY-PROBLEM, 1956-1957}

\author{
Akira OGINO \\ (Graduate School of Law, Kwansei Gakuin University)
}

[Key words: consolidation, restoration, the Nagy-problem]

\section{Introduction}

(1) The Imre Nagy-problem

János Kádár, the head of the Hungarian Socialist Workers' Party [HSWP], took the reins of government after the oppression of the Hungarian Revolution ${ }^{1}$ by a Soviet military intervention on 4 November 1956. The Kádár government faced a difficult problem, because Imre Nagy, who was the Prime Minister during the Hungarian Revolution, his colleagues took refuge at the Yugoslav Embassy in Budapest and refused to support the Kádár government. Kádár cooperated with the Soviet Union in deporting Nagy and his colleagues to Romania when they left the Yugoslav Embassy. In the end, the HSWP made a decision to prosecute them.

In the Cold War-era, many historians argued that Kádár made the decision on Nagy's prosecution due to Soviet pressure. The Soviet Union tried to strengthen the socialist bloc based on the Soviet-Yugoslav dispute after the Hungarian Revolution. ${ }^{2}$ After the end of the Cold War, the opening of the documents of the Communist Party of the Soviet Union [CPSU] and of the Hungarian National Archives was the main issue in the domestic Nagy-problem. ${ }^{3}$ Which resulted in Nagy's execution in June 1958, this was seen in a new light among Hungarian historians. Hungarian historians, György Litván and János M. Rainer argued that Kádár spontaneous prosecuted Nagy rather than being 
reluctant to the norm. ${ }^{4}$ Litván had experienced of imprisonment, because of political activities in 1956-1957. He takes a critical attitude towards Kádár.

(2) 'Consolidation' of the socialist system

The early Kádár-era was often referred to as 'Consolidation.' François FejtE, who is a French historian and is from Hungary, argued that the early Kádár-era consisted of three phases. The first phase: Reconstruction of the base of dictatorship (November-December, 1956), the second phase: Consolidation (of the socialist system) (1957-1959) and the third phase: Normalization and realization of Kádár's model (1960-). Fejtô especially emphasized that with regard to the second phase, the HSWP suppressed their opponents vehemently, and this resulted in Nagy's execution, in the process of consolidating the oneparty rule. ${ }^{5}$

Hungarian historians, Zoltán Ripp, Károly Urbán and István Fetil emphasize the suppression in the end of the 1950s. Using documents of the HSWP, which were opened after the collapse of the communist regime, they pointed out that Kádár tried to consolidate the socialist system after abandonment of economic reform in the first half of 1957 . They thought that 'Consolidation' did not only mean a period at the end of the 1950s, but continued until turning to the reformerline in the early 1960s. Ripp and Fetil redefined Fejtô's second phase, 'Consolidation' as 'Restoration', with a reference to the reconstruction of the old political system and the party organization before October of $1956 .^{6}$

(3) Kadar's political leadership

Ferenc Fehér, a Hungarian sociologist, and Bill Lomax, a British political scientist, referred to Kádár's foundation of power in the early phase as fragile. Fehér emphasized that Kádár, whose leadership in the party was fragile, was reluctant to reform and turned to the reformer-line in the 1960s to follow the de-Stalinization in the Soviet Union. ${ }^{7}$ Lomax argued that Kádár could not have carried out the reform while dealing with resistance from Stalinists and conservatives within the HSWP. ${ }^{8}$ On the contrary, Hungarian historians, Tibor Hajdu and Rainer examined that Kádár had already established his political leadership in 1957. Their research was based on documents of the HSWP, which were opened after the end of the Cold War. ${ }^{9}$

(4) The aim of this paper

Litván and Rainer argued that Kádár tried to consolidate his hold on the country by executing Nagy. The author also regards the domestic factors 
concerning the Nagy-problem as significant, although he has a different opinion from their appraisal of Kádár. Ripp, Urbán and Fetil thought that Kádár reconstructed the one-party rule on his own initiative, in the late 1950s. The author agrees with Hajdu and Rainer in thinking that Kádár could have established his leadership in 1957. Taking into account the recent trends of studies in Hungarian contemporary history, the author thinks that the Nagyproblem was closely related to the dispute over Hungary's basic policy after the Soviet military intervention and establishment of Kádár's leadership within the HSWP. This paper examines how Kádár gained his political leadership in the process of the consolidation of the socialist system through analyzing his correspondence to the Nagy-problem.

\section{The dispute within the HSWP}

The Provisional Central Committee [PCC] of the HSWP consisted of two fractions, moderates and hard-liners. A Hungarian historian, Levente Sipos argued, the two fractions had different opinions regarding the basic policy of the party and the Nagy-problem. ${ }^{10}$ In the session of the PCC on 2-3 December 1956, the dispute between the moderates and the hard-liners occurred. The concrete issue in the session was how the HSWP appraised the affair in October (the Hungarian Revolution). The differences of opinions regarding the appraisal of the affair were reflected in a dispute over forming the basic policy of the HSWP.

The moderates, József Köböl, György Aczél, Antal Gyenes and Lajos Fehér had supported Nagy before the Hungarian Revolution. The hard-liners, Kádár, Gyula Kállai, Ferenc Münnich, György Marosán, Bála Biszku, Antal Apró and József Kiss had deep distrust of Nagy and his colleagues. Nagy renounced the one-party rule during the Hungarian Revolution. Kádár and Münnich went to Moscow in the evening of 1 November. They accepted the Soviet military intervention to overthrow the Nagy government."

The author thought the hard-liners consisted of two trends, pro-Kádár and pro-Rákosi. Mátyás Rákosi was the former First Secretary of the Hungarian Worker's Party [HWP] and lost his power in July 1956. Kádár, Kállai and Marosán had experienced imprisonment during the Rákosi-era and were against Stalinism. Münnich, who was the former Ambassador in the Soviet Union, 


\section{Akira OGINO}

assumed a critical attitude towards Rákosi. Apró and Kiss had the continuity with the Rákosi-era, because both of them were members of the Politburo of the HWP. They supported Rákosi and his successor, Ernó Geró before October of 1956.

The moderates didn't regard the early phase of the affair in October as a counter-revolution. They insisted that the situation had turned counterrevolutionary from intervention of foreign imperialists, although the beginning of the armed uprising was a peaceful demonstration by democratic and patriotic people. The hard-liners insisted that from the first day of the affair, 23 October, it was already a counter-revolution. Moreover, Köböl and Gyenes criticized Nagy's deportation to Romania. Köböl said that the HSWP should have negotiated with Nagy and his colleagues, when they had left the building of the Yugoslav Embassy. Kállai laid emphasis on rightfulness of Nagy's deportation in order to defend Hungarian socialism. ${ }^{12}$

The moderates attached greater importance to responsibility of Rákosi and Geró for the breakout of the affair in October. They tried to introduce Nagy's vision of domestic reform to the basic policy of the HSWP as much as possible. On the contrary, the hard-liners stressed Nagy's responsibility for the Soviet military intervention. They wanted to maintain the frame of the party organization before 23 October, although they criticized Rákosi and Geró.

The essential problem between the two fractions was whether the HSWP should take serious consideration to continue with Nagy's reformer-line or to continue with the HWP platform before the start of the Hungarian Revolution. The moderates and the hard-liners had a consensus of opinion regarding denunciation of personality cult, and of dogmatic economic policy, which was overemphasized on heavy industry in the Rákosi-era. However, the moderates had the intention of reforming the one-party rule. The hard-liners thought that they should reform the political and economic system without changing the base of the one-party rule not to return to Stalinism. Lomax argued that Kádár had the intention of reforming the socialist system, which was unsuitable for the Hungarian circumstance, to stabilize the domestic situation. ${ }^{13}$ At the same time, Kádár had to keep good relations with the Soviet Union. He regarded the moderates, who sympathized with Nagy, as an obstacle to the stabilization of the domestic situation and to good relations with the Soviet Union. Nagy declared Hungary's withdrawal from the Warsaw Pact and the revival of a multiparty 
system during the Hungarian Revolution. Moreover, Nagy refused to resign as the Prime Minister. So Kádár followed the Soviet decision regarding Nagy's deportation to Romania, although he guaranteed Yugoslavia that Nagy and his colleagues would be allowed to return safely to their homes on 21 November. ${ }^{14}$ Kádár thought that relations with the Soviet Union and his own leadership within the party took precedence over reforming the socialist system.

In the session of the PCC on 2-3 of December, the hard-liners got an advantage over the moderates. Kádár couldn't afford to negotiate with Nagy and his colleagues until their attitude towards the Kádár government was mollified. Kádár was anxious about the rehabilitation of Rákosi, Geró and other Hungarian Stalinists in Moscow. They expected to return to Hungary and take power again, if Kádár couldn't stabilize the domestic situation. In reality, Gerö, István Kovács, a former member of the Politburo of the HWP, and András Hegedú, the former Chairman of the Ministers' Council, sent a letter to the Politburo of the CPSU on 18 November. In the letter, they criticized Kádár for the delay in restoring order. ${ }^{15}$ So there was no persuasion in the moderates' insistence, which the HSWP should have negotiated with Nagy.

On 5 December, the PCC adopted a resolution. In the resolution, the causes of the affair in October were: 1. Rákosi and Geró made mistakes, 2. Nagy and his colleagues attacked the party, 3 . The counter-revolutionary force existed in Hungary and 4. Foreign imperialists intervened in the Hungarian situation. ${ }^{16}$

It seemed that the moderates and the hard-liners compromised concerning the causes of the affair in October, because the responsibility of both the Stalinists and Nagy was written clearly in the resolution. The HSWP decided on its principle of activity, 'the two front struggle', which was against both Rákosi's dogmatism and Nagy's revisionism. Kádár tried to form a center policy. However, the generalization of the affair in October in the resolution reflected the hard-liners' view. The hard-liners insisted that the situation on 23 October had been counter-revolutionary from the beginning. ${ }^{17}$ The hard-liners strengthened the leadership within the PCC, and began to reconstruct the socialist system within the one-party rule.

\section{Reform initiated by the hard-liners}

At first, Kádár had the intention of reforming the economy to stabilize the 
domestic situation. The Hungarian economy was at a crisis, because of the Soviet military intervention and worker's strikes against the Kádár government. As a precondition of economic reform, Kádár tried to restore order by suppressing opponents. He especially took a firm attitude towards the Workers' Councils. The Workers' Councils were established during the Hungarian Revolution, and adapted a slogan of socialization of product means and self-management by workers. They supported Nagy and had planed for a general strike. The hardliners thought that the Workers' Councils were a threat to the one-party rule because the Workers' Councils could do damage to the government by strikes. The government arrested most of the members of the Workers' Council by 9 of December. $^{18}$

At the session of the PCC on 2 December, Kádár suggested the possibility of forming a people's front. ${ }^{19}$ His idea of the people's front meant the integration of non-party intellectuals, economists and specialists of the judicial system, forming the one-party rule. On 28 December, the PCC discussed to assign nonparty economists to the government organization to make a draft of reform program. ${ }^{20}$

The HSWP urged economists of the Independent Smallholder's Party, István Varga, Jenó Rácz, József Bognár to take part in committees making reform program in the government organization. Varga, Rácz and Bognár sent a letter to Kádár on 1 January 1957. In the letter, they showed their intention to cooperate with the HSWP. ${ }^{21}$ They were appointed as chairmen of the committees of the economic policy, finance and trade.

Varga, Rácz and Bognár demanded that the Independent Smallholder's Party could exist in exchange for their cooperation with the Kádár government. But Kádár was against legalizing other parties. Because the Independent Smallholder's Party cooperated with the Nagy Government.

Moreover, one of the differences of opinions between the moderates and the hard-liners was whether the pseudo-multi-party should be maintained or not. The moderates were for legalizing other parties to prevent Stalinism from reviving and to carry out the domestic reform. The hard-liners' vision of the domestic reform was to integrate economists and other specialists out of the HSWP and into the one-party rule through assigning to the government organization.

On 23 January, Kádár sent a letter to Apró, a member of the Provisional 
Executive Committee [PEC] of the HSWP. In the letter, Kádár was against legalizing the Independent Smallholder's Party in exchange for the cooperation of Varga, Rácz and Bognár in drawing up the reform program. Kádár stated that the HSWP didn't assign them as members of the Independent Smallholder's Party, but as patriots. The reform committees' existence was not provided for in the constitutional law, but was merely a working group within the government organization..$^{22}$

After deportation to Romania, Nagy and his colleagues were confined in Snagov, a neighboring Bucharest. Kállai visited Romania to persuade them to express their self-criticism in January 1957. When Kádár came into power, he wrote a synopsis of gaining Nagy's support for his government to avoid isolation in the country after the Soviet intervention. In reality, Nikita S. Khrushchev, the First Secretary of the Central Committee [CC] of the CPSU, and other Soviet leaders referred to the possibility of Nagy's joining to the new government before the military intervention. ${ }^{23}$ As Rainer argued, Kállai's persuasion was the last attempt to bring Nagy and his colleagues back to the communist regime. ${ }^{24}$ However, Nagy and his colleagues refused their self-criticism, although Zoltán Szántó, Zoltán Vas and György Lukács partially accepted Kallai’s persuasion.

Kállai reported that his persuasion ended in a rupture, in the session of the PEC on 29 January. For the first time, he suggested that Nagy and his colleagues should be subject to criminal punishment. Finally the PEC denounced a compromise with Nagy, and made a decision to investigate how Nagy and his colleagues acted during October-November 1956. ${ }^{25}$

When Nagy and his colleagues refused their self-criticism, the hard-liners did not only turn to a firm attitude towards them, but they also began to criticize pro-Nagy members within the party. As a result, the moderates who hesitated to break off Nagy's reformer-line faced a difficult situation. The moderates had to change their view of the affair in October and the Nagy-problem, if they stayed in the PCC. Fehér and Aczél turned to their position and decided to compromise with Kádár. Fehér aimed at acknowledging his own agricultural policy. Aczél tried to avoid confrontation with the hard-liners, because he had experienced imprisonment in the Rákosi-era. However, Köböl and Gyenes refused to change their view. ${ }^{26}$ In the session of the PCC on 26 February, Kádár and other hard-liners criticized Köböl severely. Köböl could not help but express self-criticism. At the same time, the PCC had a plan to frame the prosecution of 
Nagy and his colleagues, and came to a conclusion on drawing up a bill of indictment of them. ${ }^{27}$

Moreover, Kádár told off the HSWP that it would cooperate with the former member of the Independent Smallholder's Party within the limit of the Patriotic People's Front, a popular organization of the HSWP. He clearly denied the possibility of recognizing the pseudo-multiparty system. ${ }^{28}$ The hard-liners decided to get rid of personalitycult in the Rákosi-era and evils in political and economic institutions within the frame of one party-rule. They tried to break off the continuity with Nagy's radical reformer-line.

\section{Decision on Nagy's prosecution and 'Restoration'}

The delegation of the HSWP and Hungarian government visited the Soviet Union on 21 March. The head of the delegation was Kádár. At the top meeting in Moscow, Kádár and the Soviet leaders agreed to intensify the pursuits of Nagy and his colleague for injustice of counter-revolution. ${ }^{29}$ The PEC made a decision on prosecuting Nagy and his colleagues on 9 April. ${ }^{30}$ They were arrested formally and sent back to Hungary except Szántó, Vas and Lukács.

The PEC decided on prosecuting Nagy and his colleagues after the Hungarian delegation's return. It seemed that the Soviet Union made a plan of Nagy's trial and instructed Hungarian leaders to prosecute him in Moscow. However, Litván argued that Kádár and his colleagues had already made plans of the Nagytrial. ${ }^{31}$ In reality, the HSWP discussed the possibility of the Nagy-trial in the session of the PEC on 29 January and of the PCC on 26 February. ${ }^{32}$ Moreover, Boris N. Ponomarev, the head of the Department of International Affairs of the CC of the CPSU, visited Romania and met with Kállai on 8-9 March. In the report to the CC of the CPSU, Ponomarev stated that Hungarian leaders made a plan of prosecuting Nagy. ${ }^{33}$ He suggested that the CPSU should discuss as to Nagy's prosecution when the Hungarian delegation visited the Soviet Union. According to the report, Kállai told Ponomarev that Kádár, Kállai, Münnich and Marosán agreed to prosecute Nagy after the session of the PCC on 26 February. At least, it is evident that Kádár and his colleagues made preparation for the Nagy-trial before Kádár's visit to the Soviet Union. It is thinkable that through the fact regarding the decision on Nagy's prosecution, Hungary tried to take the initiative of dealing with problems arisen from the Soviet military 
intervention.

Moreover, the process of the decision indicated that the pro-Kádár hardliners, Kádár, Münnich, Marosán, Kállai and Biszku, grasped the initiative within the HSWP. When the HSWP was established, the PEC consisted of 8 members, Kádár, Münnich, Marosán, Kállai, Biszku, Apró, Károly Kiss and Fehér. The members of the PEC were the hard-liners except for Fehér. Although the hardliners took the majority in the PEC, they didn't necessarily stand together. The pro-Rákosi hard-liners, Apró and Kiss, didn't participate in the discussion about Nagy's prosecution after the session of the PCC on 26 February. Moreover, Kádár selected Biszku as the member of the PEC, even though Biszku didn't participate in the discussion. The pro-Kádár hard-liners then had the advantage over the pro-Rákosi hard-liners.

The decision on prosecuting Nagy was the turning point, for the leadership of the pro-Kádár hard-liners within the HSWP. At the same time, 'Restoration' of the old socialist system before October of 1956 began. ${ }^{34}$ From spring of 1957, the HSWP strengthened its control of the official organizations in the country. The intervention in the activity of the Catholic Church and higher educational institutions, like the Budapest University-Faculty of Law was its starting point. Regarding the organizations of the party, the Communist Youth Association was established on the model of the Soviet Comsomol. ${ }^{35}$

In the process of 'Restoration,' the economic reform came to a standstill. When the delegation of the HSWP and Hungarian Government visited the Soviet Union in March, Hungary received relief materials equivalent to one billion and 100 million rubles as well as credit equivalent to 750 million rubles from the Soviet Union. ${ }^{36}$ The economic reform program drawn up by Varga has fallen through after certainty of the prospect to reconstruct the economy. The PEC didn't discuss the content of the program in the session on 14 June. ${ }^{37}$ The proKádár hard-liners didn't recognize that they gave the reform committees led by non-party economists broad power. Regarding the return to the socialist system before October of 1956, and the standstill of the economic reform in the first half of 1957, Lomax argued that Kádár had to consolidate the one-party rule. The pressure of the Soviet Union and resistance from the conservatives in the party was too much, even though Kádár had the intention of the reform. Lomax regarded Münnich as one of the most important person among the conservatives. ${ }^{38}$ However, Münnich did not oppose Kádár's intentions, as Hajdu 
indicated..$^{39}$ On the contrary, Kádár confronted with the moderates, who adhered to Nagy's reformer-line. Restoring order and consolidating the socialist system took precedence over the economic reform.

The pro-Kádár hard-liners regarded the main enemy in 'the two front struggle' as revisionism. Kádár suppressed the opponents, who supported Nagy, and tried to strengthen his power within the party. Köböl and Gyenes were eliminated from the PCC on 24 June. ${ }^{40}$. In the National Conference of the HSWP on the 2729 June, Kádár and his colleagues formed a committee, and it was called the formal Central Committee of the HSWP. When the HSWP made a decision on prosecuting Nagy, its own course consolidating the socialist system was determined.

\section{Conclusion}

The HSWP strengthened to suppress the opponents and the control over the domestic organizations after the decision on prosecuting Nagy. In the end, Nagy was executed on 16 June $1958 .{ }^{41}$ Litván argues that Kádár was persistent with a firm attitude towards Nagy, to establish his own legitimacy in the country and surprisingly making preparations for Nagy's trial, this being because Nagy refused to resign as the Prime Minister. ${ }^{42}$ Nagy was the legitimate leader in Hungary. In reality, the HSWP carried out the Nagy-trial, although the Soviet Union treaded warily in immediate reaction to Nagy's execution. ${ }^{43}$

However, Kádár's firm attitude towards Nagy was not merely to establish his legitimacy. In spite of restoring the old socialist system, the HSWP didn't resurrect personality cult and the repressive domination with terror by the secret police (ÁVH) in the Rákosi-era. Based on the principle of 'the two front struggle', Kádár and his colleagues prohibited Rákosi and Geró from returning to Hungary, as well as preparation for the Nagy-trial. ${ }^{44}$ Kádár began to promote the deStalinization within the HSWP. After the Nagy-trial, the HSWP gradually enforced amnesties of the opponents and loosened the domestic control from 1959. Kádár brought the consolidation of the socialist system to the end in the early 1960s. The American President's Special Assistant for National Security, McGeorge Bundy reported in April 1964, 'Hungary has perhaps gone farther than any other satellite in de-Stalinizing the Communist system and the movement in that direction continues. ${ }^{45}$ 
The author thinks that Kádár's 'Restoration' was only a way of stabilizing Hungarian domestic situation and keeping good relations with the Soviet Union after the Soviet military intervention. The Soviet Union and other socialist countries had a tendency towards anti-revisionism in the late 1950s. Kádár had to extend Hungary's autonomy of domestic policy within the limitation of the Soviet bloc. A Hungarian economist and historian, Sándor Kopátsy argues that there was no alternative but Kádár. ${ }^{46}$ Kádár couldn't form his own center policy and gradual reformer-line within the frame of the one-party rule without getting rid of Nagy. The Kádár-era began, when he broke off the continuity of Nagy's radical reformer-line and initiated 'Restoration' of the old socialist system.

Notes:

1. What defined the affair in October of 1956 was closely related to raison d'être for the Kádár-regime. The Kádár-regime regarded the affair as a counter-revolution. Since the collapse of the communist regime, most historians regard the affair as a revolution in Hungary. The author also defines the affair as a revolution.

2. William Shawcross, Crime and Compromise: János Kádár and the Politics of Hungary since Revolution (New York: E. P. Dutton, 1974); Andrew Felkay, Hungary and the USSR, 1956-1988: Kádár's Political Leadership (Westport, Conneticut: Greenwood Press, 1989); François Fejtő, 1956. Budapest. l'insurrection (Bruxelles, Complexe, 1981). The author used Feitô's book translated into Japanese. The book translated into Japanese was published from the Madosya Press in Tokyo in 1990. After the end of the Cold War, a Hungarian historian Ripp argues that the Soviet-Yugoslav dispute formed the international background of the Nagy-trial. Ripp Zoltán, Belgrád és Moszkva között: A jugoszláv kapcsolat és a Nagy Imre-kérdés (1956.november-1959.február) [Between Belgrade and Moscow: Relation with Yugoslavia and the Imre Nagy-problem (November 1956-February 1959)] (Budapest: Politikatörténeti Alapítvány, 1994).

3. After the collapse of the Soviet Union, concerning the Hungarian Revolution and the Nagyproblem, 1956-1958, three documents of the CPSU were published in Hungary. Gál Éva, Hegedüs B. András, Litván György, Rainer M. János, eds., A „Jelcin-dosszié”: Szovjet dokumentumok 1956-ról [The Yeltsin-File: Soviet Documents on 1956] (Budapest: Századvég 1956-os Intézet, 1993); Vjacseszlav Szereda, Alekszandr Sztikalin, eds., Hiányzó lapok 1956 történetéböl: Dokumentumok a volt SZKP KB levéltárából [Missing Pages about History of 1956: Documents from the Archives of the Central Committee of the Former Communist Party of the Soviet Union] (Budapest: Móra Ferenc Könyv Kiadó, 1993); Vjacseszlav Szereda, Rainer M. János, eds.. Döntés a Kremlben, 1956: A szovjet pártelnökség vitái Magyarországról [Decision in the Kremlin. 1956:The Debates of the Soviet Party Presidium 'on Hungary] (Budapest: 1956-os Intézet, 1996). Minutes of the Hungarian Socialist Workers' Party Provisional Leadership, November 1956-June 1957, were published in Hungary. 


\section{Akira OGINO}

Némethné Vágyi Karola, Sipos Levente, eds., Az Magyar Szocialista Munkáspárt ideiglenes vezerö testïleteinek jegyzökönyvei l-4 (Az MSZMP jegyzökönyvei) [Minutes of the Hungarian Socialist Workers' Party Provisional Leadershipl-4] (Budapest: Intera, 1993-1994). Concerning unpublished documents of the HSWP, minutes of the Central Committee, 288.f.4.csoport, and minutes of the Politburo, 288.f.5.csoport, were in the Hungarian National Archives' possession.

4. György Litván, 'The Political Background of the Imre Nagy Trial,' in Alajos Dornbach, ed., The Secret Trial of Imre Nagy (Westport, Conneticut: Praeger, 1994); Rainer M. János, Nagy Imre 1953-1958: Politikai életrajz 2 [Imre Nagy 1953-1958: Political Biography 2] (Budapest: 1956-os Intézet, 2000).

5. François Fejtö, op.cit., pp.177-187. The author read Fejtő’s book in Japanese.

6. Ripp Zoltán, "A sztálinizmus rendszerének és restaurációjának elvi kérdéseiről [The Principal Problems of Stalinist System and Restoration]," Múltunk, 35, 1, 1990, pp.129-140; Ripp Zoltán, "Restauráció és centrumpolitika [Restoration and Center Policy]," Rubicon, 1998, 1, pp.6-11; Urbán Károly, "A kádári konszolidáció második szakasza: Véltozások az MSZMP politikai irányvonalában 1957 elején [The Second Phase of Kádár’s Consolidation: Changes in Policy of the HSWP Early in 1957]," Társadalmi Szemle, 48, 8-9, 1993, pp.115-128; Fetil István, "Kormánypolitika, 1956. november-1957. július [Government Policy, November 1956July 1957]," História, 1995, 9-10, pp.30-34.

7. Ferenc Fehér, "Kádárism as the Model State of Khrushchevism," Telos, No.40, Summer 1979, pp.19-31.

8. Bill Lomax, "The Hungarian Revolution of 1956 and the Origin of the Kádár Regime," Studies in Comparative Communism, Vol.18, No.2/3, Summer/Autumn, 1985, pp.87-113.

9. Rainer M. János, "A történelemmé vált Kádár korszak: Dokumentumok a kezdetröl [The Kádár-era Became History: Documents on the Beginning]," Évkönyv (1956-os Intézet), 4, 1995, pp.27-37; Hajdu Tibor, "Volt-e pártellenzék az MSZMP megalakulása után? [Whether Opposition in the Party existed after Formation of the HSWP?," Évkönyv (1956-os Intézet), 4, 1995, pp.39-44.

10. Sipos Levente, "Puhák és kemények: Politikai viták 1956 végén [Moderates and Hardliners: Political Debates at the end of 1956]," Rubicon, 1993, 5, pp.30-34.

11. See the Malin notes released by Russian archival authorities, regarding the session preparing to the military intervention. The author used Hungarian translation. Vjacseszlav Szereda, Rainer M. János, eds., Döntés a Kremlben. 1956, pp.75-90. Vladimir N. Malin was the head of the General Department of the CC of the CPSU.

12. Az MSZMP jegyzókönyveil, pp. 143-207.

13. Bill Lomax, op.cit., pp.104-105.

14. Kádár discussed with Mihail A. Suslov, Averkij B. Aristov, the members of CC of the CPSU, and Ivan A. Serov, the Chairman of the Committee for State Security (KGB) on 16 November. Kádár agreed on Nagy's deportation to Romania. Vjacseszlav Szereda, Alekszandr Sztikalin, eds., Hiányzó lapok, pp.235-236. See the Hungarian-Yugoslav agreement on 21 November. Kiss József, Ripp Zoltán, Vida István, eds., Magyar-jugoszláv kapcsolatok 1956, 
dokumentumok [Hungarian-Yugoslav Relations 1956, Documents] (Budapest: MTA Jelenkorkutató Bizottsága. 1995), pp.278-279. Nagy and his colleagues were taken away by the Soviet army and deported to Romania after they left the Embassy building on 22 November. 15. Gál Éva et al., eds., A ..Jelcin-dosszié", pp.133-136.

16. Az, MSZMP jegyzokönyveil, pp.238-240.

17. Ibid., pp.240-241.

18. Bill Lomax, Hungary 1956 (London: Allison\&Busby, 1976), pp.166-167. 19. Az MSZMP jegyökönyveil, pp.151.

20. Ibid., pp.282-283.

21. Közli: Némethné Vágyi Karola. Urbán Károly. Dokumentumok, az MSZMP és a többpártrendszer 1957-ben: A Vagrga-féle reformbizottság és a pártvezetés [Documents, the HSWP and the Multi-party System in 1957: The Varga Reform Committee and the Party Leadership]. In Társadalmi Szemle, 48, 1993, 8-9, pp.147-148.

22. Ibid., pp.149-150.

23. See the Malin notes. Vjacseszlav Szereda, Rainer M. János, eds., Döntés a Kremlben. 1956, pp.62-64.

24. Rainer M. János, Nagy Imre 1953-1958, pp.378-379.

25. Az. MSZMP jegyzö́könyvei2, pp.75-79.

26. Hajdu Tibor, op.cit., pp.42-43.

27. Az MSZMP jegyzökönyvei2, 170-226.o.

28. Ibid., p.165.

29. See Kádár's report in the session of the PEC on 4 April and of the PCC on 5 April. Ibid., p.348; Az MSZMP jegyzokonyvei3. p.25.

30. Ibid., pp.69-70.

31. György Litván, op.cit., p.171.

32. See note 25 and 27.

33. Vjacseszlav Szereda, Alekszandr Sztikalin, eds., Hiáyzó lapok, pp.260-263.

34. See note 6.

35. See, for example, Urbán Károly, op.cit., pp.122-124; Ormos Mária, "A konszolidáció problémái 1956 és 1958 között [The Problems of Consolidation between 1956 and 1958]," Társadalmi Szemle, 44, 8-9, 1989, op.cit., pp.55-56. 36. Urbán Károly, op.cit., pp.126.

37. See Az MSZMP jegyzökönyvei 4, pp.118-119.

38. Bill Lomax, "The Hungarian Revolution of 1956 and the Origin of the Kádár Regime," pp.104-106.

39. Hajdu Tibor, op.cit., p.43.

40. Ripp Zoltán, "Az ideiglenes korszak vége: MSZMP, 1957.május-június [The End of the Provisional Era: HSWP, May-June 1957]," Társadalmi Szemle. 48, 11, 1993, p.92.

41. On 27 May 1958, the Politburo of the HSWP decided to hold the court. Magyar Országos Levéltár, Budapest: MDP-MSZMP Iratok [Hungarian National Archives, Budapest: HWPHSWP Documents], 288.f.5/80.ô.e.

42. Görgy Litván, op.cit, p.178. Rainer also argues that Kádár carried out to execute Nagy to 


\section{Akira OGINO}

establish the legitimacy. Rainer M. János, Nagy Imre 1953-1958, p.390

43. The Soviet Union didn't desire that due to Nagy's execution Hungarian-Yugoslavian relations deteriorate more than perceived. Yugoslavia objected to the Nagy-trial. See István Sebes' memo. Kiss József, Ripp Zoltán, Vida István, eds., Magyar-jugoszláv kapcsolatok 19561959, dokumentumok [Hungarian-Yugoslav Relations 1956-1959, Documents] (Budapest: MTA Jelenkor-kutató Bizottsága, 1997), pp.361-362. Sebes was the Hungarian Deputyforeign Minister, and discussed with V. V. Astafyev, the Soviet Chargé d'affaires in Budapest, on 22 May 1958.

44. Before Kádár's visit to the Soviet Union in March 1957, the PCC of the HSWP discussed prohibiting Rákosi and Gerő from returning to Hungary. See Fetil István, "A moszkvai emigráció és az MSZMP (Rákosi Mátyás 1956-1958 között) [The Moscow Emigration and the HSWP (Mátyás Rákosi 1956-1958)]," Múltunk, 36, 4, 1991, pp.13-14. Kádár and the Soviet leaders agreed to prohibit Rákosi and Gero from returning for five years, when Kádár visited the Soviet Union in 1957. Az. MSZPM jegyzökönyvei 2, pp.346-347. In the end, Rákosi and Gero were dismissed from membership of the HSWP in 1962. Especially, Rákosi had to stay in the Soviet Union until his death of 1971.

45. See Bundy's memorandum to the President, Lyndon B. Johnson. Foreign Relations of the United States, 1964-1968, Vol.17 (Washington: United States Government Printing Office, 1996), p.301.

46. Kopátsy Sándor, Kádár és kora [Kádár and His Era] (Budapest: C.E.T. Belvárosi Kiadó, 2001), pp.148-154. 